\title{
Benjamin og korrespondancerne
}

øger rusen, denne afgrund, der blandt alle teatrets elementer uudsletteligst bærer sporene af dets sakrale oprindelse, har mistet stadig mere i betydning. Endnu ligger scenen forhøjet. Men den stiger ikke længere op af et uendeligt dyb: den er blevet podium. Lærestykke og episk teater er et forsøg på at indrette sig på dette podium.

På dansk ved Karsten Sand Iversen

\author{
CHRISTOPHER PRENDERGaSt
}

Som de fleste ved, havde Benjamin en højtudviklet smag, ja ligefrem et genialt anlæg, for det aleatoriske. Mens han snusede sig frem til de mere dunkle afkroge og utilgængelige steder inden for modernitetens område, kunne han tilfældigvis, eller i hvert fald så det så ud som et tilfælde, snuble over netop den ting, som med garanti ville overraske en, som i kraft af sin chok-virkning får en til at stille spørgsmål eller etablerer en spørgende holdning og en ny bevidsthed om det fænomen undersøgelsen gælder. Dette er en integrerende del af den Benjaminske metode, en central komponent $i$ hans mikrologi, og på det punkt står han uden tvivl temmelig meget i gæld til den kontakt han havde med surrealisterne og deres interesse for det "fundne objekt" [l'objet trouve $]$ og for hvad André Breton (noget uigennemskueligt) kaldte for det "objektive tilfælde" [hasard objectif]. Hvad mere er, så finder man også i alliancen mellem det aleatoriske og det fragmentariske (hans fragmentariske skrivemåde) en af grundene til, at Benjamin er så svær at læse. Overraskelsen bliver ofte formidlet $i$ form af en logisk eller syntaktisk ellipse eller, endnu mere radikalt, helt uden medfølgende kontekstualisering overhovedet, præsenteret uden kommentar og så at sige omgivet af tavshed.

Det er ikke min hensigt at forsøge at efterligne Benjamins metode hér. Jeg nævner imidlertid dette, fordi det er relevant for mit emne på en måde vi skal se om et øjeblik. Emnet selv er velkendt: det er korrespondancerne, en doktrin og en praksis som i særlig grad bliver associeret med Baudelaire og som jeg i nogen grad ønsker at betragte i tilknytning til Benjamin (eller rettere sagt Benjamins forhold til disse) ved hjælp af en ligeledes velkendt, men samtidig notorisk vanskelig konstellation af begreber som 
sammenbinder termer som sprog og betydning, symbol og allegori, byen og varen, melankoli og eksil, som nogle af de grundlæggende begrebsstørrelser i forbindelse med Benjamins beskæftigelse med moderniteten. Men jeg vil gerne begynde med og (efter forskellige afstikkere) tilslut vende tilbage til et punkt eller et moment $i$ denne konstellation som ikke er særlig kendt og som så vidt jeg ved ikke er blevet taget op i de foreliggende kommentarer til Benjamins opus (skønt der er meget, særlig på tysk, som jeg ikke har læst). ${ }^{1}$ Dette moment er et overraskelsens moment, $i$ det mindste er det meget overraskende for mig som er specialist i det nittende århundredes franske tænkning og litteratur. Da jeg stødte på det, gik jeg helt i stå i mine tankebaner; det fik mig til at undre mig over, hvad Benjamin forestillede sig han var i færd med at gøre i det notat der er tale om, og det fremprovokerede en hel række spørgsmål som den efterfølgende afhandling vil søge at skitsere (hvad der er svarene på disse spørgsmål er en helt anden sag).

Jeg refererer til det mærkelige moment i Baudelaire-sektionen Das Passagen-Werk, hvor Benjamin, idet han diskuterer korrespondancerne, på baggrund af sine utrættelige udgravninger i Bibliothèque Nationale's righoldige materialer, hiver et citat frem fra et værk af den ultra-konservative tænker fra det sene attende og tidlige nittende århundrede, Joseph de Maistre. De Maistre var en reaktionær teokrat og bedst kendt for sin fjendtlige holdning over for den franske revolution og over for moderniteten i almindelighed. Hans ekstraordinære bog Considérations sur la France actuelle forsvarer på baggrund af forsynstanken en katolsk opfattelse af den franske revolution som en guddommeligt inspireret katastrofe. Ifølge de Maistre endte revolutionen følgerigtigt, eller rettere sagt: teleologisk betragtet, med terrorperioden: terror-periodens excesser fuldbyrder en telos, hvorved Gud samtidig straffer Frankrig for at have annammet oplysningsprojektets verdslige værdier og frelser Frankrig fra revolutionen ved at sørge for at den falder fra hinanden i morderiske udskejelser. I den betydning ér de revolutionære uden at ville det instrumenter for den guddommelige vilje, en slags bizar Panglossianisme med omvendt fortegn. De Maistres opskrift på en tilbagevenden til ordnede forhold er et i ganske massiv forstand repressivt ideologisk og juridisk statsapparat, styret af et teokratisk præsteskab og med en energisk og yderst aktiv offentlig bøddel.

Benjamin fandt formodentlig på at læse og tænke over de Maistre som følge af sin fordybelse i Baudelaire (den ejendommeligt reaktionære Baudelaire blev under det Andet Kejserdømme i stigende grad tiltrukket af de Maistres radikalt antiliberale anskuelser). Men denne form for mere eller mindre selvfølgelig kontekstualisering er ikke mit anliggende hér (det er snarere en rutine-opgave for de akademiske udgivere af Benjamins arbejder), og desuden bliver der stadigvæk rigelig plads til fortolkning i den forbindelse. For Benjamin citerer på dette sted ikke de Maistres syn på revolutionen, moderniteten, staten, dødsstraffen osv.; han citerer de Maistre med henblik på doktrinen om korrespondancerne og desuden kontekstualiserer han citatet med henblik på, hvad vi ved er et af hans egne hovedanliggender, nemlig forskellen mellem symbol og allegori. Hér er den relevante passage:

På et betydningsfuldt sted hos de Maistre optræder allegorien ikke blot i overensstemmelse med sin sataniske oprindelse og set med de samme øjne, hvormed Baudelaire senere så den, men hér optræder også - i tilknytning til den Martinistiske og Swedenborgske mystik - korrespondancerne. Og sandt at sige udgør de på en informativ måde modstykket til allegorien. Stedet befinder sig i den ottende samtale i Soirée'erne og lyder sådan: „Man kan danne sig en helt dækkende forestilling om universet ved at anskue det $\mathrm{i}$ form af en umådelig naturhistorisk samling, som er blevet rystet af et jordskælv. Døren er åben og sprængt; der er ikke flere vinduer; hele skabe er væltet omkuld; andre hænger endnu på hængsler der er ved at rive sig løs. Konkylier er rullet ind i salen med mineraler, og en kolibris rede hviler på en krokodilles hoved. Men hvilken galning kunne dog tvivle om den oprindelige hensigt eller tro, at bygningen blev opført i denne tilstand?... Ordenen er ligeså synlig som uordenen; og øjet der går på opdagelse i dette umådelige naturens tempel, genetablerer uden besvær hvad en uheldsvanger aktør har slået i stykker eller forfalsket eller tilsølet eller anbragt forkert. Og der er mere endnu, for hvis man ser nøje efter, opdager man en hånd der har udbedret skaderne. Nogle bjælker er blevet afstivet; man har anlagt veje midt 
i ruindyngerne; og i den almindelige forvirring har en mængde analogier allerede genindtaget deres pladser og rører ved hinanden. ${ }^{2}$

Mit spørgsmål er da, hvad vi skal stille op med dette moment? Hvad jeg ønsker at gøre med det (hvad jeg forsøger at gøre i forbindelse med et andet projekt vedrørende kulturpolitikken i Frankrig i det nittende århundrede) er at dreje Benjamins tænkning om korrespondancerne hen $i$ retning af et sted hvor æstetik og politik skærer hinanden. Når man tager de karakteristiske ellipser i Benjamins tænkning i betragtning, er det ikke så let en opgave. Vi bliver ofte nødt til selv at drage en række slutninger og endda nøjes med rent gætværk. Hvad der følger nu er i det store og hele netop dette.

Lad mig først minde om doktrinen om korrespondancerne, sådan som den optræder hos Benjamins hovedkilde, Baudelaire. Groft sagt figurerer korrespondancerne i Benjamins æstetiske og kritiske skrifter inden for tre dimensioner: en psykologisk, en æstetisk og en metafysisk. Den psykologiske dimension har at gøre med den perceptionsteori, som teknisk set kaldes for synæstesi, d.v.s. den proces hvorved én sanse-perceptions orden kan fremkalde eller blive oversat til en anden orden (den olfaktoriske fremkalde den visuelle, den visuelle den auditive, o.s.v.). Den æstetiske dimension vedrører det gensidige påvirkningsforhold imellem kunstarterne og den måde hvorpå de kan konverteres til hinanden, hvorved f.eks. maleriets farver kan fremmane musikkens tonesystem og vice versa, en forestilling som sidenhen bliver formaliseret i Wagners og symbolisternes idé om det totale kunstværk (den model af et Gesamtkunstwerk der beskrives i Wagners teoretiske arbejder antyder allerede en forbindelse til en vis form for politik af en temmelig skræmmende art, en totalitær art, sådan som denne forbindelse bliver udkastet i Adornos bog om Wagner). Endelig er der den metafysiske dimension, som hidrører fra en anti-oplysnings-tradition for mystisk tænkning som strækker sig fra Jakob Böhme gennem Swedenborg og ind $i$ det nittende århundrede. Nøglebegrebet er hér systemet af korrespondancer, som forener det jordiske og det transcendentale, det materielle og det spirituelle, et symbolsk og analogisk sprog givet til mennesket af Gud før Syndefaldet, som sikrer en uafbrudt fremadskriden fra det naturlige til det guddommelige. Systemet befinder sig så at sige på en lodret akse, hvor det fungerer både som arche og telos, oprindelse og slutpunkt, forsåvidt angår meningen med kosmos. Det er denne metafysiske doktrin Baudelaire refererer til i sit essay om Victor Hugo som den gudgivne „universelle analogi” og som i en vis udstrækning også bliver formuleret i den berømte sonet "Correspondances" igennem billedet af naturen som en "skov af symboler".

De forskellige akser i teorien om korrespondancerne konvergerer i en term, som er central for Baudelaires æstetik og for flere retninger inden for det nittende århundredes tænkning generelt, herunder den sociale og politiske tænkning. Det drejer sig om begrebet harmoni, en musikalsk analogi som Baudelaire gjorde til sin egen så tidligt som i Salonen fra 1845 og som han gjorde til grundlag for en hel æstetik. Som analogien indebærer, er det kunstens formål at forene og syntetisere, at overvinde splittelse og fragmentering og erstatte dissonans med konsonans. Jeg vil fă lejlighed til at vende tilbage til dette ord, "harmoni".

Det er altså, i hvert fald i et vist omfang, ved hjælp af disse termer Benjamin diskuterer korrespondance-princippet i Baudelaires værk. For Benjamin er korrespondancerne hos Baudelaire forbundet med et projekt, som går ud på at sætte en brudt erfaring sammen igen (",korrespondancerne gengiver et erfaringsbegreb", i den rige og facetterede betydning af dette begreb, som det tyske ord Erfahrung indebærer). ${ }^{3}$ Den psykologiske mekanisme som genererer processen er erindringen; "Korrespondancer," skriver Benjamin, „er hukommelsens data”. 4 Således fører korrespondancerne $\mathrm{i}$ forening med erindringsarbejdet til og legemliggør en tilbagevenden til et begyndelsespunkt, et første øjeblik, hvor væren på en lykkelig måde var udelt. Hos Baudelaire er dette karakteristisk nok tematiseret som en gentilegnelse af barndommen (,„l' enfance retrouvée à volonté", som han formulerede det i sit essay om Delacroix) eller mere generelt en tilstand før syndefaldet, hvis mytiske form i vores kultur er Edens Have, det tabte paradis (for nu at nævne et eksempel) i digtet i Les Fleurs du Mal, hvor han fremmaner „de parfumerede paradiser...den barnlige kær- 
ligheds grønne paradis". Lyrisk poesi baseret på korrespondancer er kongevejen til en retrospektiv tilgang til en tabt værensharmoni, iscenesat f.eks. i et digt som „Parfum exotique”, en poetisk tekst konstrueret som et synæstetisk netværk af analogier som oversætter én sanse-orden til en anden, og hvor udgangspunktet er kontakten med en kvindes bryst (,Når...på en mild efterårsaften / Jeg indånder duften af dit varme bryst..."); i almindelighed identificeres brystet som en elskerindes bryst, men det kunne med ligeså fuld ret blive associeret med en fantasi om en tilbagevenden til moderkroppen.

Denne brug af korrespondance-princippet, hvor det benyttes til at fremmane eller ligefrem genskabe en tabt enhed, er tydeligvis regressiv. På modernitetens betingelser er den struktur der knytter sig til Erfahrung fiktiv, og den bliver overskygget af en nostalgisk længsel efter "noget som er gået uigenkaldelig tabt". ${ }^{5}$ Benjamin ser det således hos Baudelaire som en form for ønskeopfyldelse og en form for selv-projicering, som reflekterer et forsøg på at pakke et fragmenteret selv sammen igen $\mathrm{i}$ hvad han kalder en "krise-fast form", 6 d.v.s. en form som beskytter psyken mod de chok som den moderne livsform medfører, især i storbyen. I en sådan beskrivelse fremprovokerer korrespondance-princippet derfor i det store og hele en negativ vurdering; det er hverken modent eller ærligt. Men dersom det er tilfældet, er det på den anden side i modstrid med nogle andre tendenser og commitments hos Benjamin, fremfor alt med dem der har at gøre med den såkaldt "mystiske” side hos Benjamin og som på en afgørende måde kommer til udtryk i forbindelse med hans sprog-og symbolteori.

For mystikeren Benjamin leger med en opfattelse af sproget ved hjælp af termer, som minder om doktrinen om korrespondancerne (Michael Jennings citerer f.eks. Benjamin som en person, der tror fuldt og fast på et netværk af "hemmelige affiniteter" som underlag for „en åndelig og psykologisk forbindelse mellem mennesket og dets verden“), ${ }^{7}$ og hér er udtrykket „hemmelige affiniteter" en direkte gentagelse af Théophile Gautiers "affinités secrètes", og Gautier er på sin side en af Baudelaires vigtigste forløbere. De hemmelige affiniteter mellem ting udgør også en del af baggrunden for Benjamins særlige version af "symbolet". I Benjamins skrifter (og først og fremmest i de tre essays „Om den mimetiske evne", "Om sproget i almindelighed og om menneskets sprog” og „Doktrinen om ligheder”) bliver symbolbegrebet artikuleret ved hjælp af benævnelsen, en primær benævnelsesakt som finder og sammennitter en enhed imellem materie og ånd. „Kun igennem tingenes sproglige essens kan mennesket nå ud over sig selv og erhverve sig viden om dem - i Navnet". 8 Dette er Benjamins version af en sproglig kratylisme eller - eftersom det snarere er Hamann end Platon der fungerer som kilde hér - en version af sprogets adamiskeoprindelse som en form for ur-oprindelig benævnelse.

Et andet navn for Navnet er symbolet; og det er på symbolsiden, at korrespondancerne hører til..$^{9}$ Forsåvidt som impulsen bag korrespondancerne går ud på at sætte en brudt erfaring sammen igen, at gøre helt hvad tiden og historien har splittet ad, har korrespondancerne lod og del i symbolets enhedslige, a-temporale status, hvor psyke og krop ikke er adskilt og signifiant og signifié ikke er to forskellige ting; hvor repræsentationen også er præsentation eller bedre udtrykt en legemliggørelse - $\mathrm{i}$ den betydning, at der er tale om en præsens $i$ tegnet af det som tegnet betegner. ${ }^{10}$ På samme måde som korrespondancernes metafysiske dimension er intimt forbundet med den romantiske panteisme, $\mathrm{i}$ kraft af hvilken det guddommelige er tilstede overalt i den naturlige verden, således stammer også deres litterære korrelat fra den romantiske æstetiske ideologi, hvor der drømmes om et oprindeligt øjebliks uformidlede udtryk, idet ord og ting, betydning og form sammen med fremtræden og væsen er ét.

De problemer der knytter sig til denne forestilling om en oprindelig sproglig og betydningsmæssig condition humaine er naturligvis velkendte: $\mathrm{i}$ bedste fald er der tale om en spekulativ fabel og i værste om en indholdsløs fantasiforestilling. Under alle omstændigheder: hvis paradiset er det sted, hvor vi var engang, er det i hvert fald ikke, hvor vi er nu, eller hvor det er sandsynligt vi nogensinde kommer. Den messianske side hos Benjamin stiller den mulighed i udsigt, at historien kunne føre til en genåbning af paradisets porte - en tro, som knytter sig til det vel- 
kendte begreb om kritik som Rettung og forløsnings-teorien om sprogets og kulturens rolle. På den anden side antyder den katastrofiske vision af historien, som bliver skitseret $\mathrm{i}$ „Om historiens begreb", at det er en meget fjerntliggende mulighed. Og det er helt sikkert, at portene er lukket ind til hvad Benjamin kalder for moderniteten, en verden som guderne har forladt for længe siden - hér er Benjamin tæt på Hölderlin - og overladt til en reel tilstand af splittelse: arbejdsdeling, psykens selvafvigelse og tegnets selvafvigelse. På disse betingelser er menneskets sprog ( $\mathrm{i}$ ental eller flertal) ikke den symbiotiske benævnelses sprog, konsubstantialiteten mellem ord og ting. Det er et byttemiddel, hvor tegn er abstrakte og arbitrære (i Saussures betydning), d.v.s. brikker som er underlagt udskiftelighedens lov - ikke Edens, men Babelstårnets sprog.

For Benjamin betyder moderniteten mange ting, men først og fremmest er den lig med kapitalismens modernitet, som er tæt på i tid, og med vare-formens kultur. Benjamins refleksioner over varens fantasmagori og dens forbindelse til symbolets og allegoriens respektive regimer er begribeligvis et emne som mange har taget op, og jeg har selv ikke noget nyt at føje til denne diskussion. Sandt at sige ønsker jeg at bevæge mig $i$ en helt anden retning. Men det er nødvendigt at følge denne sti hen over velkendt terræn, så man må tilgive mig nogle af selvfølgelighederne i de få præliminære bemærkninger jeg fremsætter om det pågældende område.

For det første lader det simpelthen til, at nogle mennesker mener, at kortlægningen af dette terræn er en helt simpel affære. Det er det ikke; eller hvis det er det, må en mængde fortolkningsmæssigt oprydningsarbejde først foretages i forhold til hvad der ser ud som en række formidable uklarheder. Nogle af udsagnene i Passage-projektet ser logisk set selvmodsigende ud - på en sådan måde, at skellet mellem symbol og allegori og i sammenhæng hermed vare-formens fantasmagori kommer til at fremtræde med utydelige omrids. F.eks. formulerer Benjamin sig på et bestemt sted kategorisk på følgende måde: „Baudelaire idealiserer oplevelsen af varen ved at tilskrive oplevelsen af allegorien som dens paradigme“ (J 66,1 [dvs. J 66,2; cf. Walter Benjamin: Ge- sammelte Schriften, Band V,1, Das Passagen-Werk, Frankfurt am Main: Suhrkamp, 1991, p. 436]). Og senere i samme sektion af Passage-projektet hedder det: „[Det Baudelaireske drømmeris] sindbillede, allegorien, passede perfekt til varefetichismen" $(J$ 79a,4 [cf. Benjamin, op. cit., p. 465]).

Overfladisk set tager disse påstande sig mærkelige ud. For som Benjamin hævder andetsteds, idealiserer allegorien ikke varen; tværtimod afmystificerer den den; og i overensstemmelse hermed bliver allegorien ikke et billede på varefetichismen; den udstiller snarere varens fetichistiske karakter, som vare-formen forsøger at tildække. Så ved første øjekast er der tale om selvmodsigelser hér; men som jeg bemærkede, vil jeg overlade det til de virkelige eksperter at finde ud af det. Til mit formål vil jeg gå ud fra, at det primære sigte i Benjamins argumentation er, at den udtryksmåde, der korresponderer bedst med varen, er symbolet. Selvfølgelig tager det sig ud som en pervers liaison; for symbolet og varen kunne se ud til at være hinandens diametrale modsætninger, omvendte spejlbilleder af hinanden; symbolet er ren transparens, basis for et ",reelt nærvær" (for at bruge George Steiners formulering); varen er en løgn, et påskud, et simulacrum for symbolet, som bevirker en form for hypnose, hvor vi fejlagtigt forveksler fremtrædelse og væsen (hvad Susan Buck-Morss i sin kommentar til Benjamin har kaldt for et "laterna magica-show med optiske illusioner"). ${ }^{11}$

Men hvad hvis symbolet nu også var en løgn, hvis det selv var en form for fantasmagori, en slags forførerisk laterna magicashow?12 Selve ordet "magi“", som spiller så væsentlig en rolle i Marx' analyse af varen, er også et vigtigt begreb i Baudelaires æstetik, først og fremmest i forbindelse med den plads korrespondancerne indtager i hans opfattelse af den lyriske poesi. Poesien er for Baudelaire, med en berømt formulering, "en suggestiv magi" og „et manende kogleri“, hvad der understøtter en forestilling om poesiens funktion som en gen-fortryllelse (i den fulde, quasimagiske betydning af ordet "gen-fortrylle") af modernitetens verden, hvor al trolddom er borte. Poesiens forføreriske magt bliver på denne måde netop overskygget af en foruroligende angst, en frygt for at poesien ikke er andet end taskenspillerkunster, en 
kilde til illusioner på præcis samme måde som varen, d.v.s. et laterna magica-show, og som følge heraf genstand for ironi.

Ironien hører til på allegoriens side, og allegoriens funktion er at fortælle sandheden om varen; dens rolle er at "rydde hele grunden og fjerne bedragets og mytens underskov" (N 1,4 [Benjamin, op. cit., p. 571]). Allegorien idealiserer ikke vare-formen; den afslører snarere den vilkårlighed og kunstighed, som er forklædt som fetichens fantasmagori, og den demonstrerer, at varens „betydning" ikke er noget der hører naturligt til den, men tværtimod er noget som bliver konstitueret i kraft af en ækvivalens- og ombytningslogik, hvorved betydninger kan fluktuere på samme måde som priser: „Betydningsmåder [i virkeligheden står der: „Betydningens moder" (!), oversætterens anmærkning] skifter ligeså hurtigt som varernes priser. De facto er varens betydning dens pris; som vare har den ikke nogen anden. Det er af tydning dens pris; som ver er i sit rette element sammen med varen“ (J 80,2 [Benjamin, op. cit., p. 466]). Allegorien er på denne måde en form for anti-magisk tænkning, som hænger sammen med af-fortryllelse, tab, eksil, melankoli og sorg over vores udstødelse af det paradis, som den strategiske brug af de poetiske korrespondancer celebrerer. Den genskaber i de menneskelige frembringelser tiden, forfaldet og mangelen, dvs. den manglende sammenhæng imellem det materielle og det transcendentale.

Hos Baudelaire kan dette, på den poetiske praksis' niveau, oversættes til en dobbelt negativ bevægelse bort fra den eufori, som ellers er investeret i korrespondancerne. Den første bevægelse - som iøvrigt ikke bliver bemærket af Benjamin selv - hænger sammen med den måde hvorpå den retoriske økonomi i korrespondancerne $\mathrm{i}$ et vist omfang bryder sammen, f.eks. i den berømte sonet som hedder "Correspondances". Jeg har hér i tankerne den bevægelse i digtet, som Paul de Man har analyseret, hvorigennem den retoriske krumtap i digtet, ordet "comme", som kitter den analogiske struktur i digtet sammen, sluttelig bryder sammen i den sidste tercet, hvor den sidste forekomst af der sammen i comme" ikke længere er en term der henviser til et analogisk forhold, men i grammatisk forstand er en helt anderledes og semantisk langt mere udtømt term, som benyttes til ren opremsning og henviser til en liste snarere end til en sammenligning. ${ }^{13}$ Den anden bevægelse er den som Benjamin har lagt mærke til, hvor der finder et skift sted i den måde korrespondancerne konciperes på - fra symbol til allegori, fra den naturlige verden til den menneske-frembragte kunstige verden - samtidig med at den poetiske teksts fabriksmæssigt fremstillede karakter i den fabriksmæssige fremstillings æra bliver tydeligt demonstreret. Korrespondancerne bliver på denne måde transformeret og afmystificeret $i$ kraft af, at de bliver sat i et nært forhold til den kontingente måde fabriksmæssig fremstilling hos menneskene i første instans er blevet til som produktionsmåde. På den måde bliver Korrespondancerne holdt adskilt fra enhver formodet forbindelse med en guddommelig og tidløs oprindelse. De hører nu uigenkaldeligt til tiden og historien og således, i Benjamins optik, til det syndrom som omfatter ruinerne og ødelæggelsen af "harmonien". Som han formulerer det i sin Zentralpark-tekst: „,Baudelaires allegori bærer ... præg af en vrede der var så voldsom, at den brød ind $i$ denne verden og efterlod dens harmoniske strukturer i ruiner". ${ }^{14}$ I kraft af allegoriens mellemkomst bliver Baudelaires verden overskygget af ødelæggelsens genfærd, den udmattelse der, som Benjamin formulerer det, indsætter „århundreder" mellem nutiden og det forudgående øjeblik, hvad der er en stærkt svækket form for différance, som muliggør det markante træk hvorved Baudelaire placerer hvad Benjamin kalder "antikken“ i selve hjertet af moderniteten.

For at opsummere kan vi da postulere en sammenhæng imellem korrespondancerne, symbolet og varen, hvorved korrespondancerne bliver til en genstand eller en kategori, som man kan mistænke for at være en form for mystifikation og som i sidste instans bliver ruineret af allegoriens modsatrettede kraft. Dette er imidlertid kun ét kapitel i den relevante historie. Og plottet spidser så at sige meget mere til, når vi vender os til det andet kapitel, nemlig det kapitel som i særlig grad angår mig hér, og som vil føre mig tilbage til mit udgangspunkt i Joseph de Maistres skrifter. For hvis symbolets og korrespondancernes økonomi hænger snævert sammen med vare-ideologien, hvordan kan det 
så være at doktrinen om korrespondancerne udøvede en sådan tiltrækningskraft på tankebygninger, som var demonstrativt fjendtlige over for de versioner af den sociale modernitet som frembragte vare-kulturen, dvs. den anti-oplysnings-tradition og den anti-kapitalistiske kritik som, forsåvidt angår den udformning den fik i England, blev beskrevet af Raymond Williams i hans bog Culture and Society?

Dette spørgsmål bringer os frem til det sted hvor æstetik og politik skærer hinanden. Hvad Benjamin angår, så er der i den sammenhæng mulighed for at vælge mellem (mindst) to veje. Den ene fører os hen til en social tænkning af utopisk karakter i begyndelsen af det nittende århundrede, først og fremmest i Fouriers skrifter. Fourier tilpassede til en form for socialteori og historisk profeti præcist det begreb som Baudelaire brugte, da han dannede sig sin tidlige opfattelse af den lyriske poesi, nemlig begrebet "harmoni“. Harmonien eller hvad Fourier kaldte den Harmoniske Orden, hvis fysiske udtryk er falanstèrens kommunitariske model, er det som skal afløse den uorden der hersker inden for hvad Fourier kalder Civilisationen. Civilisationen er på den anden side hvad vi med Benjamin ville kalde for kapitalismen, d.v.s. det rationaliserede system med den moderne arbejdsdeling og specialiseringen af funktionerne, dét samfund med rettigheder og kontrakter og konkurrencepræget individualisme, som fører frem til de cirkulations- og ombytningssystemer der tilskriver varen en sådan prestige; kort sagt, udskiftningen af Gemeinschaft med Gesellschaft, en erstatning som Fouriers skema søger at vende på hovedet i form af en projektion hen imod en utopisk fremtid, hvor det tabte paradis bliver generobret.

Til mit formål er den vigtige pointe hér, at korrespondance-princippet spiller en grundlæggende rolle i konstruktionen af dette scenarie. Det teoretiske fundament for Fouriers samfundsmodel er helt klart metafysisk eller endda kosmologisk og bygger på idéen om en ur-oprindelig enhed skænket til mennesket af guderne og hvis form er den universelle analogis - eller hvad han med et tilsvarende udtryk kalder for "tiltrækning". Analogier, fællestræk, ligheder er hvad der binder kosmos sammen og hvad der binder menneskene til kosmos og til hinanden i en samarbej- dets ånd, som bliver perverteret og ødelagt ved Civilisationens fremkomst. Der er også, skønt dette ikke er centralt for Fouriers hovedanliggende, en korrespondance-æstetik på spil (et sted skitserer han en litterær version af korrespondancerne baseret på idéen om en form for prosa-poesi, der som et netværk af analoge interaktive termer kunne siges at fungere som en artistisk analogi for det utopiske samfund).

Vi ved selvfølgelig; at Baudelaire før 1848 var stærkt interesseret i Fourier, og vi ved også at Benjamin delte denne interesse. Fouriers skrifter figurerer på en central måde i Passage-projektet; og i forbindelse med Benjamins kontakter med den franske surrealisme, først og fremmest den fraspaltede gruppe omkring Bataille, har Klossowski oplyst os om, at under gruppens møder med Benjamin var det de helst ville diskutere med ham hans interesse i Fourier. ${ }^{15}$ Men Baudelaire skulle snart opgive sin interesse for Fourier (hans henvisninger til Fourier efter 1848 er næsten uden undtagelse utvetydigt ringeagtende), idet han bevægede sig i retning af en helt anden politik; og det er usandsynligt, at Benjamin i længere tid skulle føle sig underlagt Fouriers vision af en gen-åbning af paradisets porte. For dersom Fourier har blikket rettet mod fremtiden, så er det så at sige et tilbagerettet blik der fikserer en oprindelses-ontologi. Den fourieristiske utopi er ikke blot en frembringelse, men også en generobring af en enhed som er skrevet ind i verden af Gud og som mennesket efterfølgende har mistet.

Organicistiske forestillinger om et menneskeligt samfund før Syndefaldet hører i høj grad til den traditionelle anti-oplysningskritik fra det sene attende århundrede og fremover, og meget ofte er de dybt reaktionære forsåvidt angår deres politiske tendens. Dette er den anden af de to veje, som doktrinen om korrespondancerne kan få os til at slå ind på. Joseph de Maistre hører på sin egen hysteriske måde til denne tradition, og dersom Baudelaire i stigende grad bliver interesseret i de Maistre, er det fordi han ligeledes i sine senere år reagerer mod den sækulariserede, varebaserede orden der er karakteristisk for den kapitalistiske modernitet og han gør det med formuleringer, der i sig selv kunne kaldes for hysterisk-reaktionære, hvis det da ikke var fordi hys- 
terien gerne er indfældet $i$ en ejendommelig, hyppigt indtil det ulæselige uigennemsigtig form for ironi.

Det er på denne måde vi kan begynde at finde en mening i korrespondance-teoriens politik, i de Maistres tilsynekomst i Benjamins forskningsprojekt og endelig i Benjamins egen tiltagende skepsis over for en doktrin, som han andetsteds og specielt i sine sprogteorier havde følt sig så fristet af. For der er også en sprogteori hos de Maistre eller rettere sagt en teori om sprogets oprindelse der minder utrolig meget om den kratylistiske eller adamiske fantasiforestilling som Benjamin selv, via Hamann, havde følt sig tiltrukket af. I sin historisk-politiske og metafysiske traktat Essai sur le principe générateur des constitutions politiques (som viderefører nogle af argumenterne i den tidligere Considérations sur la France actuelle) vier de Maistre adskillige kapitler til spørgsmål der drejer sig om sproget og betydningen. I begyndelsen var Navnet, og navnet bliver skænket os af Gud (,Kun Gud har ret til at give et navn"). ${ }^{16}$ Navne er ikke arbitrære tegn (,Navne er ingenlunde arbitrære ${ }^{\prime \prime}$; 17 de er ikonisk og onomatopoetisk motiverede, det vil sige, de ligner eller snarere legemliggør i selve deres materialitet det de betegner. Denne teori om Navnet indebærer også en prioritering af talen på bekostning af skriften. Talen er det levende sprog, budskaber af guddommelig oprindelse kodesat i menneskets åndedræt; skriften er på den anden side det døde bogstav og de levende menneskelige institutioners død ( skriftens intethed inden for rammerne af de store institutioner" ${ }^{\prime 18}$

Hér har vi en version af det menneskelige samfund baseret på en guddommeligt forfattet og autoriseret logos. ${ }^{19}$ Det er begribeligvis en anti-oplysnings-teori, et angreb på konventionalistiske måder at fremstille sproget på, som drejer sig om instrumentalitet $\mathrm{og}$ bytteforhold og hører sammen med den rationaliserede, tslige og moderne bytteøkonomi. Moderniteten er efter de Maistres opfattelse en version af Syndefaldet, et frafald fra nådetilstanden eller, med et udtryk hvor nøglebegrebet fra Baudelaires korrespondance-æstetik kommer til syne igen, et tab eller en formindskelse af harmoni(en): „Idet grundtonen i vores skabelses-system er blevet stemt ned, er alle de andre toner blevet stemt tilsvarende ned, i overensstemmelse med harmoniens grundprincipper. “20

Hvis dette skal læses som en kritik af ødelæggelsen af $\mathrm{Ge}$ meinschaft igennem et fremmedgørende og tingsliggørende $\mathrm{Ge}$ sellschaft, er det meget svært at læse det med nogen grad af sympati. ${ }^{21}$ I de Maistres system bliver det guddommeligt forfattede Navns prestige karakteristisk nok overført til kriger-kasten, til sejrherrerne og erobrerne, som en belønning for deres bedrifter, og den bliver ydermere associeret politisk med dannelsen af national-staten: „Og jeg, jeg tror, og jeg ved, at ingen menneskelig institution kan vare ved, medmindre den har et religiøst fundament; og derudover heller ikke (jeg beder om at man vil lægge godt mærke til dette), hvis den ikke bærer et navn som stammer fra et nationalsprog og hidrorer fra sig selv, uden at man benytter sig af nogen forudgående og i forvejen kendte overvejelser." 22 Hér er drømmen om et sprog forbundet med et renset politisk legeme, renset gennem vold og opretholdt gennem undertrykkelse. De Maistres opfattelse af et guddommeligt sanktioneret og velreguleret samfund handler i bund og grund om et afstraffelsessamfund, en ur-version af hvad vi idag kalder for totalitarismens politik.23

Hermed kan vi meget vel, med en helt særlig indsigt, vende tilbage til det moment i Passage-projektet, hvor Benjamin citerer de Maistre angående korrespondancerne og antyder en forbindelse til spørgsmålet om symbolet og allegorien. Symbolets politik kommer i den sammenhæng til at fremtræde som en legemliggørelsens politik (signifié' en i signifiant' en), forsåvidt som den arketypiske form for legemliggørelse er Staten. Dette var også et tema i den tyske romantik, hvor det drejede sig om frembringelsen af hvad de Man kalder en æstetisk ideologi, og som han sætter i nær forbindelse med det tyvende århundredes fascisme. Dette er en højst kontroversiel påstand, og jeg vil med det samme selv sige, at den form for ræsonnement som sætter Schiller sammen med Goebbels og i den romantiske æstetiske ideologi ser en lige linje frem til udryddelseslejrene ikke blot er tåbelig, men ligefrem forfærdelig, særlig forsåvidt som en sådan tankegang fremviser nøjagtig de samme elementer af en anakronistisk og teleologisk tænkning, som de Man i det dekonstruktive hjørne var så opsat 
på at afvise. Ikke desto mindre ser det ud, som om der for Benjamin på det tidspunkt hvor han arbejdede med Passage-projektet eksisterede en eller anden form for forbindelse mellem symbolet og den totalitære politik, og denne kobling hang især sammen med hvad Benjamin senere kaldte æstetiseringen af politikken under fascismen. Der er begribeligvis et teoretisk alternativ til at finde en mening med Benjamins henvisning til de Maistre. Det er næsten ikke til at bære at tænke på, men måske bør man gøre det alligevel: nemlig hvis man læser Benjamins korte møde med de Maistre som båret af sympati. Det ville på den anden side indebære, at man blev nødt til at acceptere, at der de facto findes en "autoritær" politik hos Benjamin, venstredrejet og eksplicit sat $i$ et modsætningsforhold til fascismen, men i sin logiske struktur beslægtet med den „politiske teologi“ hos Carl Schmitt (som selv var en stor beundrer af de Maistre). ${ }^{24}$

Jeg har hér plæderet for en mere skeptisk og verdslig Benjamin, skønt det måske har haft den skæve (og helt usandsynlige) konsekvens, at han kommer til at fremtræde som et barn af oplysnings-projektet. Sandt at sige er der et langt skridt fra doktrinen om korrespondancerne til dette, og jeg er helt på det rene med, at jeg har skudt genveje og er sprunget over et terræn med gabende huller under fødderne. Hvad jeg hér foreslår er en antiteologisk læsning af Benjamin, men begribeligvis er forudsætningen for en sådan læsning en række kontroversielle påstande angående det "teologiskes“ status hos Benjamin; forsåvidt angår de relevante termer (det paradisiske, det faldne og det messianske), er det uklart, hvorvidt Paradiset, Syndefaldet og Messias betegner historiske kategorier, eller om disse er psykologiske og erfaringsbaserede - som metaforer i en fænomenologi der beskriver begærets og erindringens struktur. ${ }^{25}$ Men den måde at se sagen på, jeg har skitseret, forekommer mig i det mindste at være et muligt udgangspunkt, en arbejdshypotese, når det gælder om at finde en mening med dette under andre synsvinkler så sære, lidt forvirrende moment i Passage-projektet.

\section{Oversat af Ib Johansen.}

\section{Noter}

Jeg har (med en enkelt undtagelse) valgt at oversætte de tyske og franske citater i Prendergasts artikel (de står på originalsproget i hans tekst) (Oversætterens bemærkning).

1. Det omtales f.eks. ikke i den imponerende detaljerede rekonstruktion på engelsk af Passage-projektet, som Susan Buck-Morss har foretaget.

2. Walter Benjamin: Das Passagen-Werk, Gesammelte Schriften, V-1 (Frankfurt am Main, 1982), p. 471 [dvs. p. 477 (!)].

3. Walter Benjamin: ",Some Motifs in Baudelaire", in: Charles Baudelaire: A Lyric Poet in the Era of High Capitalism (London, 1973), p. 139. „Experience" skal hér forstås som hvad Benjamin kalder for Erfahrung og som i essayet "Some Motifs in Baudelaire“ bliver defineret pa falgeng og som "Hvor der er erfaring ['experience'] i den præcise betydning af ordet, bliver elementer fra den individuelle fortid kombineret med elementer fra den kollektive fortid" (p. 113).

4. Ibid., p. 141

5. Ibid., p. 139

6. Ibid., p. 140 .

7. Michael Jennings: Dialectical Images. Walter Benjamin's Theory of Literary Criticism (Ithaca, New York, 1978), p. 85. Scholem hæudede imidlertid kategorisk, at Benjamins sprogteori var splittet i selve sit grundlag formedelst en uforløst modsigelse imellem mystisk-magiske og skeptisk-materialistiske begreber. Gershom Scholem: Walter Benjamin: The Story of a Friendship (Philadelphia, 1981), p. 209.

8. Walter Benjamin: „On Language as Such and on the Language of Man“, in: Reflections (New York og London, 1978), pp. 316-17.

9. Cf. Lloyd Spencer: "Allegory in the World of the Commodity: The Importance of Central Park", New German Critique, No. 34 (Winter 1985) p. 63.

10. Cf. Susan Buck-Morss: The Dialectics of Seeing. Walter Benjamin and the Arcades Project (Cambridge, Mass., og London, 1989), p. 168.

11. Susan Buck-Morss, op. cit., p. 81 .

12. I almindelighed skelner fortolkere af Benjamin mellem det "gode" symbol (den ",teologiske“ variant) og det "dårlige“ symbol, baseret på et sækulariset simulacrum, som står for den virkelige ting. Cf. Jennings, op. cit., p. 167. Det er imidlertid uklart, hvad der er grundlaget for denne distinktion, medmindre man opfatter "teologi“ helt bogstaveligt, hvad der på den anden side ville indbefatte, at man skulle opfatte alle de hermed forbundne religiose begreber bogstaveligt, ikke mindst begreber som Oprindelsen og Syndefaldet.

13. Paul de Man: The Rhetoric of Romanticism (New York, 1984), p. 249.

14. Walter Benjamin: Central Park, New German Critique, No. 34 (Winter 1985), p. 20. 
15. Pierre Klossowski: „Between Marx and Fourier“, in: On Walter Benjamin. Critical Essays and Recollections, ed. Gary Smith (Cambridge, Mass., og London, 1991), pp. 367-70.

16. Joseph de Maistre: Essai sur le principe générateur des constitutions politiques et autres institutions humaines (Paris 1814, genoptrykt Strasbourg, 1959), p. 87.

18. Ibid., p. 40.

19. Joseph de Maistre var imidlertid ikke en romantisk panteist. Hans teori om det guddommeligt forfattede ord er foreneligt med den kristne åbenbarings-doktrin, og begrebet om Guds levende ord er ikke det samme som det panteistiske begreb om Naturen som et legemliggørelsens sprog, hvor transcendentale idéer bliver legemliggjort. Hamanns doktrin var iøvrigt heller ikke forskellig fra de Maistres, cf. Charles Taylor: Hegel (Cambridge, 1975), p. 27 (note).

20. Joseph de Maistre: Considérations sur la France actuelle (Paris, 1852), p. 48.

21. Jeg henviser begribeligvis hér til forbindelsen mellem de Maistres sprogteori og hans præskriptive politik. På det rent deskriptive og analytiske plan er de Maistres fremstilling af sammenhængen mellem den verdslige modernitet og volden profund. Dette antyder på den anden side, at karakteren af Baudelaires interesse for de Maistre fortjener en langt mere nuanceret behandling, end jeg har været i stand til at give hér. Den mere omfattende kontekst ville i den sammenhæng være hele den eksisterende tradition for en højreradikal kulturkritik rettet mod moderniteten, en tradition som frembringer tankeformer der er foruroligende, men også fra et diagnostisk synspunkt hyppigt dybdeborende. Det forklarer formodentlig, hvorfor en kritiker på venstrefløjen som Raymond Williams følte sig så tiltrukket af dem, i det mindste af de udformninger de fik på engelsk grund.

22. Joseph de Maistre, op. cit., pp. 85-86.

23. Den måde man har tilegnet sig de Maistre på i de ekstreme højrebevægelser i det tyvende århundrede bliver reflekteret i en skræmmende lille bog forfattet af en Action Française sympatisør ved navn Paul Carcoural, som sammenligner de Maistres idéer med tankegodset hos Charles Maurras: Les Idées politiques de Joseph de Maistre et la doctrine de Charles Maurras (La Rochelle, 1929). Når man tager Action Française's anti-semitisme i betragtning, er der måske noget bittert ironisk i det forhold, at Benjamin også stødte på teokratiske fantasier og tilsvarende forestillinger om et magisk åbenbaringssprog hos en jødisk tænker, Oskar Goldberg (som foreslog en numerologisk læsning af Tora'en og, for at henvise til Scholems opsummering, en „genskabelse af det magiske forbund imellem Gud og hans folk“). Scholem fortæller, at „Benjamin følte så stærk en antipati imod ham, at han ved en bestemt lejlighed var fysisk ude af stand til at trykke den hånd Goldberg havde strakt frem imod ham for at hilse" (Scholem, op. cit., p. 97). Scholem antyder selv dristigt en konvergens imellem den nazistiske ideologi og Goldbergs fantastiske spekulationer ved hjælp af en reference til Thomas Manns Doktor Faustus („Dér optræder Goldberg som den lærde Dr. Chaim Breisacher, en slags metafysisk super-nazist, der præsenterer sin magiske raceteori med omtrent Goldbergs egne ord", ibid., p. 271).

25. Med hensyn til nogle idéer vedrørende det „autoritære" hos Benjamin og den mulige forbindelse til Carl Schmitts tænkning, cf. Rainer Rochlitz: Le désenchantement de l'art. La philosophie de Walter Benjamin (Paris, 1992), p. 271

26. I sin diskussion af den „mystiske" side af Benjamins sprogteori benægtede Scholem, at brugen af teologiske kategorier på nogen måde var metaforisk; tværtimod hævdede han, at Benjamin „kunne tale helt umetaforisk om 'Guds ord' og holde dem helt klart adskilt fra menneskelige ord" (Scholem, op. cit., p. 209). 